\title{
Efficacy and safety of tranexamic acid usage in patients undergoing posterior lumbar fusion: a meta-analysis
}

\author{
Jianzhong Bai ${ }^{1,2+}$, Pei Zhang ${ }^{1 \dagger}$, Yuan Liang ${ }^{1}$, Jingcheng Wang ${ }^{1 *}$ and Yongxiang Wang ${ }^{1 *}(\mathbb{D}$
}

\begin{abstract}
Background: The purpose of this meta-analysis is to evaluate the efficacy and safety of tranexamic acid (TXA) for patients with degenerative lumbar disc herniation, stenosis or instability undergoing posterior lumbar fusion (PLF) surgery.

Methods: We searched PubMed, Embase, and Cochrane Library until May 1, 2018. Two reviewers selected studies, assessed quality, extracted data, and evaluated the risk of bias independently. Weighted mean difference (WMD) and relative risk (RR) were calculated as the summary statistics for continuous data and dichotomous data, respectively. We chose fixed-effects or random-effects models based on $I^{2}$ statistics. RevMan 5.0 and STATA 14.0 software were used for data analysis.

Results: Nine studies enrolling 713 patients for the study. The pooled outcomes demonstrated that TXA can decrease total blood loss (TBL) in patients underwent PLF surgery [WMD $=-250.68,95 \% \mathrm{Cl}(-325.06,-176.29), P<$ 0.001], intraoperative blood loss (IBL) [WMD $=-72.57,95 \% \mathrm{Cl}(-103.94,-41.20), P<0.001]$, postoperative blood loss (PBL) $[\mathrm{WMD}=-127.57,95 \% \mathrm{Cl}(-149.39,-105.75), P<0.001]$, and the loss of hemoglobin $(\mathrm{Hb})$ in postoperative $24 \mathrm{~h}$ $[W M D=-0.31,95 \% \mathrm{Cl}(-0.44,-0.18), P<0.001]$. However, there is no significant difference between two groups in transfusion rate $[\mathrm{RR}=0.34,95 \% \mathrm{Cl}(0.09,1.28), P=0.11]$, and none thrombotic event was happened in the two groups.

Conclusion: Our meta-analysis demonstrated that TXA can decrease the Hb loss, TBL, IBL, PBL, and without increasing the risk of thrombotic event in patients with degenerative lumbar disc herniation, stenosis or instability underwent PLF surgery. However, there was no significant difference in blood transfusion rates between the two groups.
\end{abstract}

Keywords: Tranexamic acid, Posterior lumbar fusion, Blood loss, Lumbar degenerative disease, Spinal surgery

\section{Background}

Posterior lumbar fusion (PLF) has achieved satisfactory results in the treatment of lumbar degenerative diseases. However, this surgical procedure was associated with substantial blood loss during the perioperative setting, which increases intraoperative hypotension, invisible operative field, postoperative neural compression, infection, anemia, and other morbidities. Blood transfusion could correct anemia, but it

\footnotetext{
*Correspondence: wangjcyangzhou@163.com; wyx918spine@163.com

${ }^{\dagger}$ Jianzhong Bai and Pei Zhang contributed equally to this work.

'Department of Orthopedics, Clinical Medical College of Yangzhou

University, Northern Jiangsu People's Hospital, Nantong West Road 98,

Yangzhou 225001, China

Full list of author information is available at the end of the article
}

could cause some complications, such as hemolytic reaction, electrolyte disturbances, and infectious diseases $[1,2]$. Therefore, it is necessary to reduce the blood loss for patients who underwent spinal surgery [3].

TXA can block the lysine binding sites of plasminogen, plasmin, and tissue plasminogen activator to delay fibrinolysis and blood clot degradation $[4,5]$. This drug has a significant hemostatic effect in obstetric surgery, hip or knee joint replacement, and coronary-artery surgery [6-8]. Previous meta-analyses have shown that TXA can significantly reduce blood loss in spinal surgery [9-12]. However, these studies included multiple types of surgical procedures, different surgical approaches, and areas. Recently, two meta-

(c) The Author(s). 2019 Open Access This article is distributed under the terms of the Creative Commons Attribution 4.0 International License (http://creativecommons.org/licenses/by/4.0/), which permits unrestricted use, distribution, and reproduction in any medium, provided you give appropriate credit to the original author(s) and the source, provide a link to the Creative Commons license, and indicate if changes were made. The Creative Commons Public Domain Dedication waiver (http://creativecommons.org/publicdomain/zero/1.0/) applies to the data made available in this article, unless otherwise stated. 
analyses demonstrated that patients treated with TXA had a significantly lower blood loss in scoliosis surgery [13, 14]. It is well known that scoliosis surgery is extremely complicated, which operation time and blood loss are far more than the PLF surgery for lumbar degenerative diseases. It is unclear whether TXA has a similar effect in PLF surgery to the scoliosis surgery. Therefore, we conducted the metaanalysis to evaluate the efficacy and safety of TXA in PLF surgery for the treatment of lumbar degenerative diseases.

\section{Materials and methods}

This meta-analysis was performed according to the Preferred Reporting Items for Systematic Reviews and MetaAnalysis (PRISMA) statement [15].

\section{Literature search}

We searched the PubMed, Embase, and Cochrane Library from the date of their inception to May 1, 2018, and no language limited. Additionally, the references of the included studies were manual searched to find additional studies. The following keywords were used in the database search: "Tranexamic acid", "Posterior lumbar fusion", "Lumbar degenerative disease", and "Spinal surgery".

\section{Study selection and eligibility criteria}

Inclusion criteria: 1) control group is placebo or saline, experimental group is TXA; 2) endpoints: TBL, IBL, $\mathrm{PBL}$, postoperative $24 \mathrm{~h} \mathrm{Hb}$ decline, transfusion rate, and thromboembolic events; 3) study designs were randomized controlled trials (RCTs) and case-control trials (CCTs); 4) patient is older than 18 years.

Exclusion criteria: 1) other types of spinal disorders, such as scoliosis, Duchenne muscular dystrophy, spine fractures; 2) other study designs did not provide sufficient data, such as case report, review, commentary, and so on; 3) there was duplicate publication.

\section{Data extraction}

We extracted the general characteristics from each study: author, published year, sample size, age, patient type, study design, the dose of TXA, transfusion criteria, and outcome measures. Any discrepancies were resolved following discussion. The endpoints included TBL, IBL, PBL, postoperative $\mathrm{Hb}$ decline, transfusion rate, thromboembolic events.

\section{Quality assessment}

The quality of the RCTs was accessed by the 12-items scale [16]. The score of more than 7, 5-7, and less than

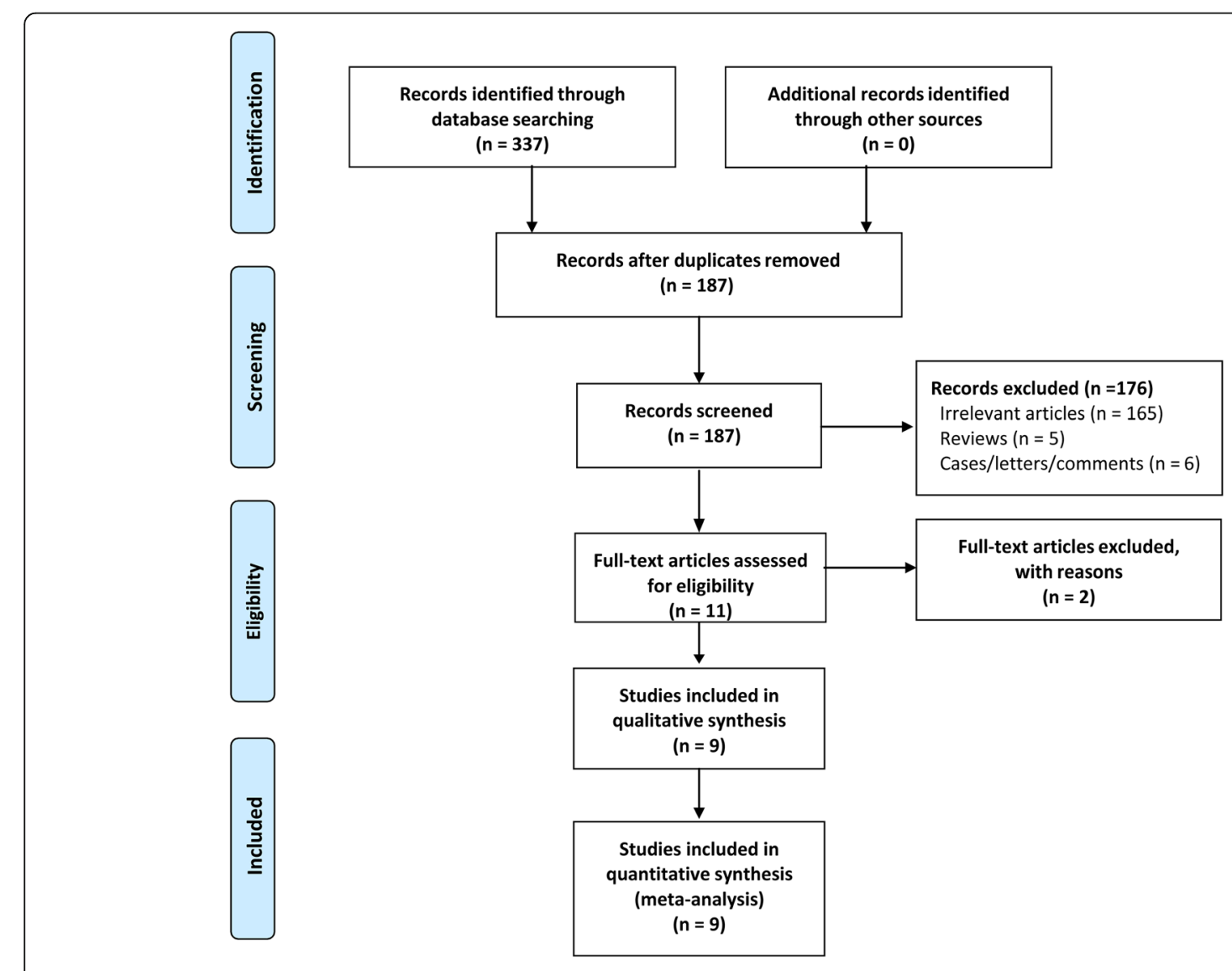

Fig. 1 The flow chart of studies selecting 
Table 1 Characteristics of the included studies

\begin{tabular}{|c|c|c|c|c|c|c|c|c|}
\hline $\begin{array}{l}\text { Study } \\
\text { (year) }\end{array}$ & $\begin{array}{l}\text { No. } \\
\text { T } \\
\text { VS } \\
\text { C }\end{array}$ & $\begin{array}{l}\text { Mean } \\
\text { age } \\
\text { (years): } \\
\text { T VS C }\end{array}$ & $\begin{array}{l}\text { Preoperative } \\
\mathrm{Hb}(\mathrm{g} / \mathrm{dl}, \mathrm{T}: \mathrm{C})\end{array}$ & $\begin{array}{l}\text { Study } \\
\text { design }\end{array}$ & Patient type & Dose of TXA & $\begin{array}{l}\text { Transfusion } \\
\text { criteria }\end{array}$ & $\begin{array}{l}\text { Outcome } \\
\text { measures }\end{array}$ \\
\hline $\begin{array}{l}\text { Endres } \\
2011[28]\end{array}$ & $\begin{array}{l}46 / \\
51\end{array}$ & $67 / 69$ & $14.91 / 14.51$ & $\mathrm{CCT}$ & $\begin{array}{l}\text { Lumbar degenerative } \\
\text { spinal stenosis and } \\
\text { instability }\end{array}$ & $\begin{array}{l}1 \mathrm{~g} \mathrm{IV} \text { preoperative, } 6 \mathrm{~h} \text { and } 12 \mathrm{~h} \\
\text { postoperative respectively }\end{array}$ & NR & (2)(3)(4) \\
\hline $\begin{array}{l}\text { Wang } \\
2013[20]\end{array}$ & $\begin{array}{l}30 / \\
30\end{array}$ & $63.1 / 62$ & $13.7 / 14.1$ & $\mathrm{RCT}$ & $\begin{array}{l}\text { Lumbar degenerative } \\
\text { spinal stenosis and } \\
\text { instability }\end{array}$ & $\begin{array}{l}15 \mathrm{mg} / \mathrm{kg} \text { mixed in } 100 \mathrm{ml} \text { saline before } \\
\text { surgery }\end{array}$ & NR & (1)(2)(3)(6) \\
\hline $\begin{array}{l}\text { Kushioka } \\
2016[26]\end{array}$ & $\begin{array}{l}30 / \\
30\end{array}$ & $\begin{array}{l}67.8 / \\
71.5\end{array}$ & $13.3 / 13.3$ & CCT & $\begin{array}{l}\text { Lumbar degenerative } \\
\text { disease (single } \\
\text { institution) }\end{array}$ & $\begin{array}{l}2000 \mathrm{mg} \text { IV, preoperative and } 16 \mathrm{~h} \\
\text { postoperative surgery respectively }\end{array}$ & NR & (1)(2)(3)(4)(5) \\
\hline $\begin{array}{l}\text { Liang } \\
2016[21]\end{array}$ & $\begin{array}{l}30 / \\
30\end{array}$ & $\begin{array}{l}51.13 / \\
53.83\end{array}$ & $13.96 / 13.5$ & $\mathrm{RCT}$ & $\begin{array}{l}\text { Lumbar degenerative } \\
\text { spinal stenosis }\end{array}$ & $2000 \mathrm{mg}$ in $20 \mathrm{ml}$ saline solution soaked & $\mathrm{Hb}<7 \mathrm{~g} / \mathrm{dl}$ & (2)(3)(4)(5) \\
\hline $\begin{array}{l}\text { Roopa } \\
2017[24]\end{array}$ & $\begin{array}{l}25 / \\
25\end{array}$ & $69.0 / 70$ & NR & $\mathrm{RCT}$ & $\begin{array}{l}\text { Lumbar degenerative } \\
\text { disease (single } \\
\text { institution) }\end{array}$ & $\begin{array}{l}10 \mathrm{mg} / \mathrm{kg} \text { IV before surgery and } 1 \mathrm{mg} / \mathrm{kg} / \\
\mathrm{hr} \text {. till closure. }\end{array}$ & $\mathrm{Hb}<8 \mathrm{~g} / \mathrm{dl}$ & (2)(3)(4)(6) \\
\hline $\begin{array}{l}\operatorname{Kim} 2017 \\
{[22]}\end{array}$ & $\begin{array}{l}24 / \\
24 / \\
24\end{array}$ & $\begin{array}{l}61 / 63.3 / \\
65.2\end{array}$ & $\begin{array}{l}13.1 / 13.3 / \\
13.2\end{array}$ & $\mathrm{RCT}$ & $\begin{array}{l}\text { Lumbar degenerative } \\
\text { disease (single } \\
\text { institution) }\end{array}$ & $\begin{array}{l}\mathrm{HD} \text { group received } 10 \mathrm{mg} / \mathrm{kg} \text { in } 100 \mathrm{~mL} \text { of } \\
\text { normal saline, and } 2 \mathrm{mg} / \mathrm{kg} / \mathrm{h} \text { until } 5 \mathrm{~h} \\
\text { after surgery. LD group half of the dose }\end{array}$ & NR & (1)(2)(3)(4) \\
\hline $\begin{array}{l}\text { Ren } 2017 \\
{[27]}\end{array}$ & $\begin{array}{l}50 / \\
50\end{array}$ & $\begin{array}{l}55.2 / \\
58.7\end{array}$ & $13.91 / 13.92$ & CCT & $\begin{array}{l}\text { Lumbar disc herniation } \\
\text { or lumbar spinal stenosis }\end{array}$ & $1 \mathrm{~g}$ in $100 \mathrm{~mL}$ saline solution soaked & $\mathrm{Hb}<7 \mathrm{~g} / \mathrm{dl}$ & (1)(2)(3)(6) \\
\hline $\begin{array}{l}\text { Shi } 2017 \\
{[23]}\end{array}$ & $\begin{array}{l}50 / \\
46\end{array}$ & $\begin{array}{l}57.7 / \\
55.3\end{array}$ & $13.5 / 13.7$ & $\mathrm{RCT}$ & $\begin{array}{l}\text { Lumbar spinal stenosis } \\
\text { or lumbar } \\
\text { spondylolisthesis }\end{array}$ & $\begin{array}{l}30 \mathrm{mg} / \mathrm{kg} \text { i.v before skin incision, and a } \\
\text { maintenance dosage of } 2 \mathrm{mg} / \mathrm{kg} / \mathrm{h} \text { TA } \\
\text { until skin closure }\end{array}$ & $\mathrm{Hb}<7 \mathrm{~g} / \mathrm{dl}$ & (1)(2)(3)(4)(5) \\
\hline $\begin{array}{l}\text { Ou } 2018 \\
{[25]}\end{array}$ & $\begin{array}{l}59 / \\
59\end{array}$ & $64.2 / 64$ & $12.8 / 12.9$ & $\mathrm{RCT}$ & $\begin{array}{l}\text { Lumbar degenerative } \\
\text { spinal stenosis and } \\
\text { instability (double } \\
\text { institutions) }\end{array}$ & $\begin{array}{l}15 \mathrm{mg} / \mathrm{kg} \text { i.v after anesthesia, and } 1.0 \mathrm{~g} \text { in } \\
10 \mathrm{~mL} \text { of normal saline soaked }\end{array}$ & $\begin{array}{l}\mathrm{Hb}<9.0 \mathrm{~g} / \\
\mathrm{dl}\end{array}$ & (1)(2)(3)(4)(5)(6) \\
\hline
\end{tabular}

(1)Total blood loss (2)Intraoperative blood loss (3)Postoperative blood loss (4)Postoperative $24 \mathrm{~h}$ hemoglobin decline (5)Transfusion rate (6Thromboembolic events iv: intravenous; Hb: hemoglobin; HD: high-dose; LD: low-dose; T: tranexamic acid group; C: control group; RCT: randomized controlled trial; CCT: case control trial

5 was considered as high, moderate, and low quality, respectively. The Newcastle-Ottawa Scale was used to assess the quality of non-RCTs [17]. We set the score of $0-3,4-6$, and 7-9 for low, moderate, and high quality of the study, respectively.

\section{Data analysis and statistical methods}

We used Revman 5.0 software and Stata14.0 to make statistical analyses. Weighted mean difference (WMD) and relative risk (RR) were calculated as the summary statistics for continuous data and dichotomous data, respectively. Two-tailed $P<0.05$ was regarded as statistically significant. Statistical heterogeneity was assessed by the $\mathrm{I}^{2}$ statistic, and $\mathrm{I}^{2}$ value more than $50 \%$ indicates significant heterogeneity, less than $50 \%$ is considered acceptable. We performed subgroup analyses based on the route of administration, study designs and the quality of studies.

\section{Results}

\section{Search result}

Two reviewers independently undertook the searches according to the search strategy. A total of 337 articles were retrieved, Endnote X8 (version 18.0.0.10063) was used to remove 150 duplicate studies. Additionally, we deleted 176 irrelevant articles through the title and abstract. Two studies were excluded according to full texts, which one article was duplicate publication [18] and the other did not have a suitable control group [19]. Finally, nine studies were included. The study selection process was shown in Fig. 1.

\section{Study characteristics}

Six of nine were RCTs [20-25], and three were CCTs [26-28]. These studies were published between 2011 and 2018, with sample sizes ranging from 50 to 118 subjects, a total of 713 subjects, and the procedure with TXA was performed on 368 subjects. The main characteristics of the included trials are summarized in Table 1.

\section{Study quality}

The quality of RCTs was shown in Table 2. Four studies were of high quality [20, 22-24], and two studies were of moderate quality [21, 25]. Details of the quality assessment of CCTs were shown in Table 3 . The average score was 8.3 (range, 8-9), suggesting that all the studies were of high quality. 





Table 3 The Newcastle-Ottawa Scale appraisal scores for the non-RCTs

\begin{tabular}{|c|c|c|c|c|c|c|c|c|c|}
\hline \multirow[t]{2}{*}{ Study } & \multicolumn{4}{|l|}{ Selection } & \multirow[t]{2}{*}{ Comparability } & \multicolumn{4}{|l|}{ Outcome } \\
\hline & $\begin{array}{l}\text { Definition of } \\
\text { cases }\end{array}$ & $\begin{array}{l}\text { Cases } \\
\text { Representativeness }\end{array}$ & $\begin{array}{l}\text { Selection of } \\
\text { Controls }\end{array}$ & $\begin{array}{l}\text { Definition of } \\
\text { Controls }\end{array}$ & & $\begin{array}{l}\text { Assessment of } \\
\text { Exposure }\end{array}$ & $\begin{array}{l}\text { Same } \\
\text { Methods }\end{array}$ & $\begin{array}{l}\text { Non- } \\
\text { Response } \\
\text { Rate }\end{array}$ & $\begin{array}{l}\text { Total } \\
\text { Score }\end{array}$ \\
\hline $\begin{array}{l}\text { Endres et } \\
\text { al. }\end{array}$ & * & $*$ & * & $*$ & * & * & * & * & 8 \\
\hline $\begin{array}{l}\text { Kushioka } \\
\text { et al. }\end{array}$ & $*$ & * & * & * & * & * & * & * & 8 \\
\hline Ren et al. & * & * & * & * & $* *$ & * & * & * & 9 \\
\hline
\end{tabular}

Single asterisk indicates 1 score, double asterisk indicates 2 scores, and dash indicates 0 scores

\section{Clinical outcomes}

\section{Total blood loss ( $\mathrm{ml}$ )}

TBL was available from six studies [20, 22, 23, 25-27], and the pooled outcomes demonstrated that the TXA could significant decrease TBL [WMD $=-250.68,95 \% \mathrm{CI}$ (-325.06, - 176.29), $P<0.001, \mathrm{I}^{2}=73 \%$, Fig. 2].

\section{Intra-operative blood loss ( $\mathrm{ml}$ )}

IBL was available from nine studies [20-28], and the results demonstrated that the TXA could significant decrease IBL [WMD $=-72.57,95 \%$ CI $(-103.94,-41.20)$, $P<0.001, \mathrm{I}^{2}=58 \%$, Fig. 3].

\section{Post-operative blood loss ( $\mathrm{ml}$ )}

PBL was available from nine studies [20-28], and the pooled ooutcomes demonstrated that the TXA could significant decrease PBL [WMD $=-127.57$, 95\% CI (149.39, - 105.75), $P<0.001, \mathrm{I}^{2}=83 \%$, Fig. 4$]$.

\section{Postoperative $24 \mathrm{~h}$ hemoglobin decline ( $\mathrm{g} / \mathrm{dl}$ )}

Seven studies $[21-26,28]$ provided available data and the pooled outcomes demonstrated that the TXA group had a lower postoperative $\mathrm{Hb}$ decline value [WMD = 0.31, 95\% CI $(-0.44,-0.18), P<0.001, \mathrm{I}^{2}=29 \%$, Fig. 5].

\section{Transfusion rate and thromboembolic events}

Transfusion rate was available from three studies [21, 23, 25], and the pooled outcomes indicated that no significant difference between the two groups $[\mathrm{RR}=0.34,95 \% \mathrm{CI}(0.09,1.28)$, $P=0.11, \mathrm{I}^{2}=68 \%$, Fig. 6]. Besides, none thrombotic event was happened in the two groups [20, 24, 26-28].

\section{Funnel plot analysis}

IBL and PBL were used to generate the funnel plot analysis of publication bias (Fig. 7). The symmetric characteristic of the pooled plot indicated that no significant publication bias (Begg's test: $P=0.917$ for IBL, Fig. 7a; Begg's test $P=0$. 118 for PBL, Fig. $7 b)$. Due to the limited number of studies included, so publication bias was not evaluated in other outcomes.

\section{Subgroup analysis \\ Different routes of administration}

We conducted a subgroup analysis based on the route of administration (shown in Table 4). TBL was available from four studies [20, 22, 23, 26], and the pooled outcomes demonstrated that the intravenous TXA (IV TXA) could significant decrease TBL [WMD $=-287.25$, 95\% CI $\left.(-411.81,-162.70), P<0.001, \mathrm{I}^{2}=79 \%\right]$. Besides,

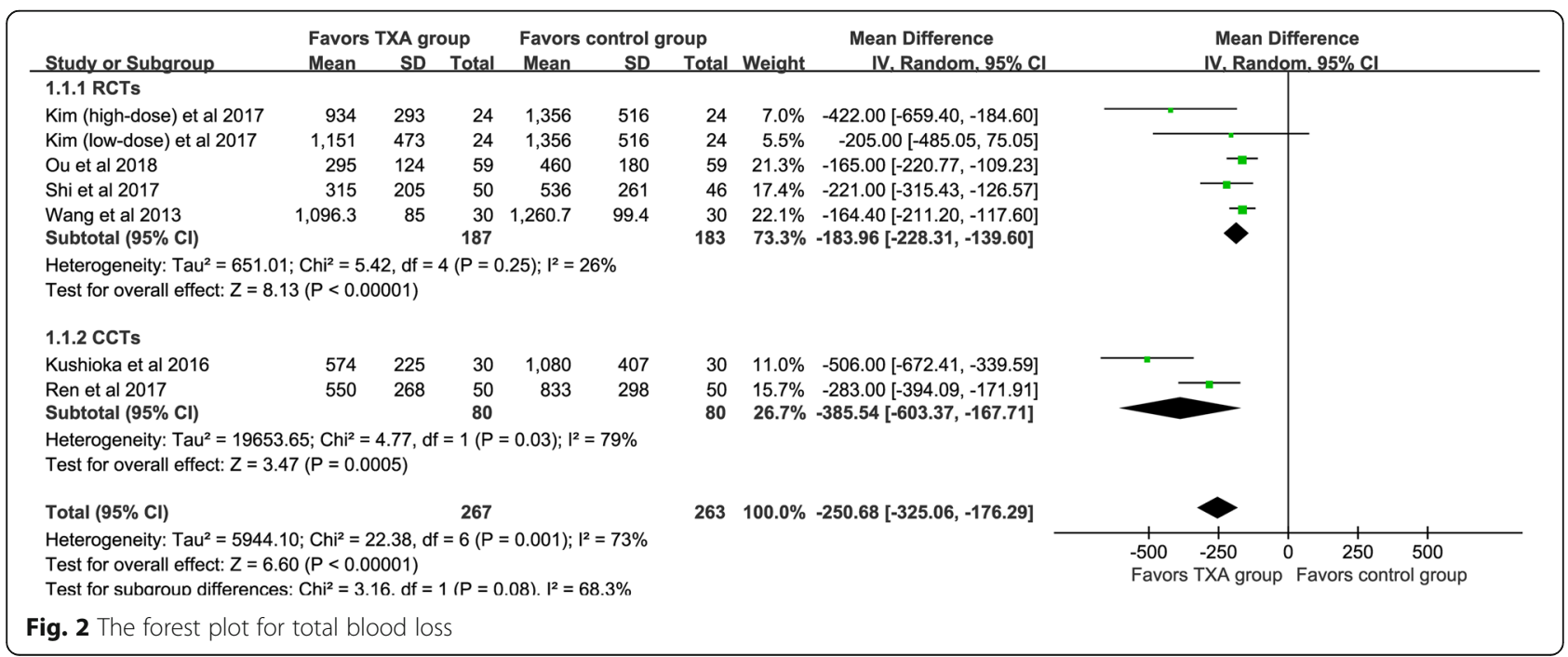




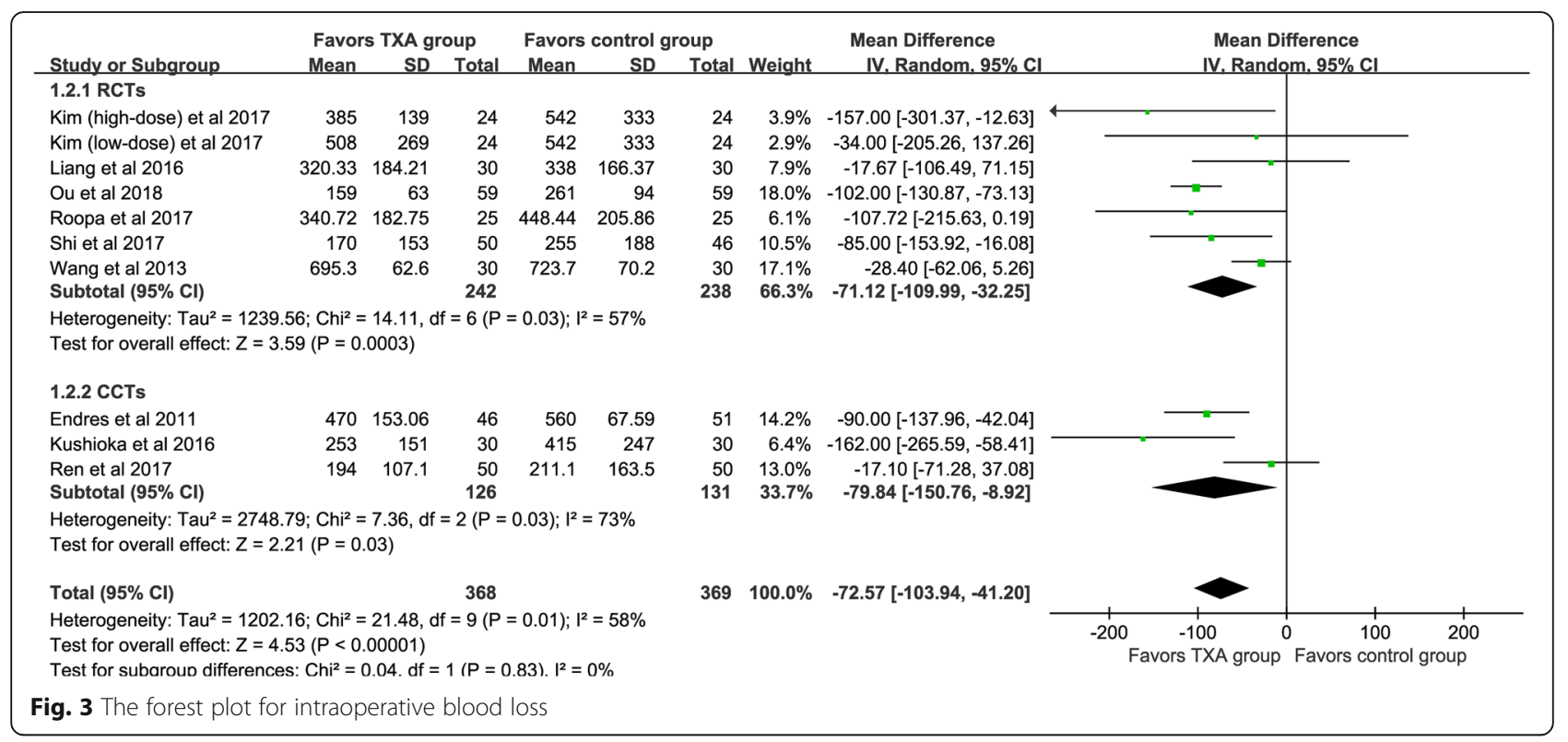

the TBL significantly decreased in topical use of TXA (tTXA) group $(P<0.001)$ [27] and combined IV with topical administration of TXA group $(P<0.001)$ [25]. For IBL, six studies $[20,22-26]$ provided available data and the results demonstrated that the IV TXA could decrease IBL [WMD $=-82.73,95 \%$ CI $(-122.80,-42.66)$, $\left.P<0.001, \mathrm{I}^{2}=48 \%\right]$. Two studies $[21,27]$ reported available data, and the results suggested that the tTXA group could not decrease IBL significantly [WMD $=-17.25$, 95\% CI $\left.(-63.51,29.00), P=0.46, I^{2}=0 \%\right]$. One study [25] demonstrated that the combined IV with topical administration of TXA could significant decrease IBL $(P<$ $0.001)$. For PBL, six studies [20, 22-24, 26, 28] provided available data and the pooled results demonstrated that the IV TXA can significant decrease PBL [WMD = 135.66, 95\% CI $\left.(-164.24,-107.08), P<0.001, \mathrm{I}^{2}=84 \%\right]$. Two studies [21, 27] reported available data, and the pooled results suggested that the tTXA could significant decrease PBL [WMD $=-119.17,95 \%$ CI $(-210.40$, 27.94), $\left.P=0.01, \mathrm{I}^{2}=71 \%\right]$. One study [25] demonstrated that the combined IV with topical administration of TXA could decrease PBL $(P<0.001)$. We further conducted a subgroup analysis for postoperative $24 \mathrm{~h}$ hemoglobin decline based on the route of administration (shown in Table 4). Five studies [22-24, 26, 28] provided available data and the results demonstrated that the IV TXA group with a lower postoperative $\mathrm{Hb}$ decline value [WMD $\left.=-0.28,95 \% \mathrm{CI}(-0.42,-0.14), P<0.001, \mathrm{I}^{2}=32 \%\right]$.

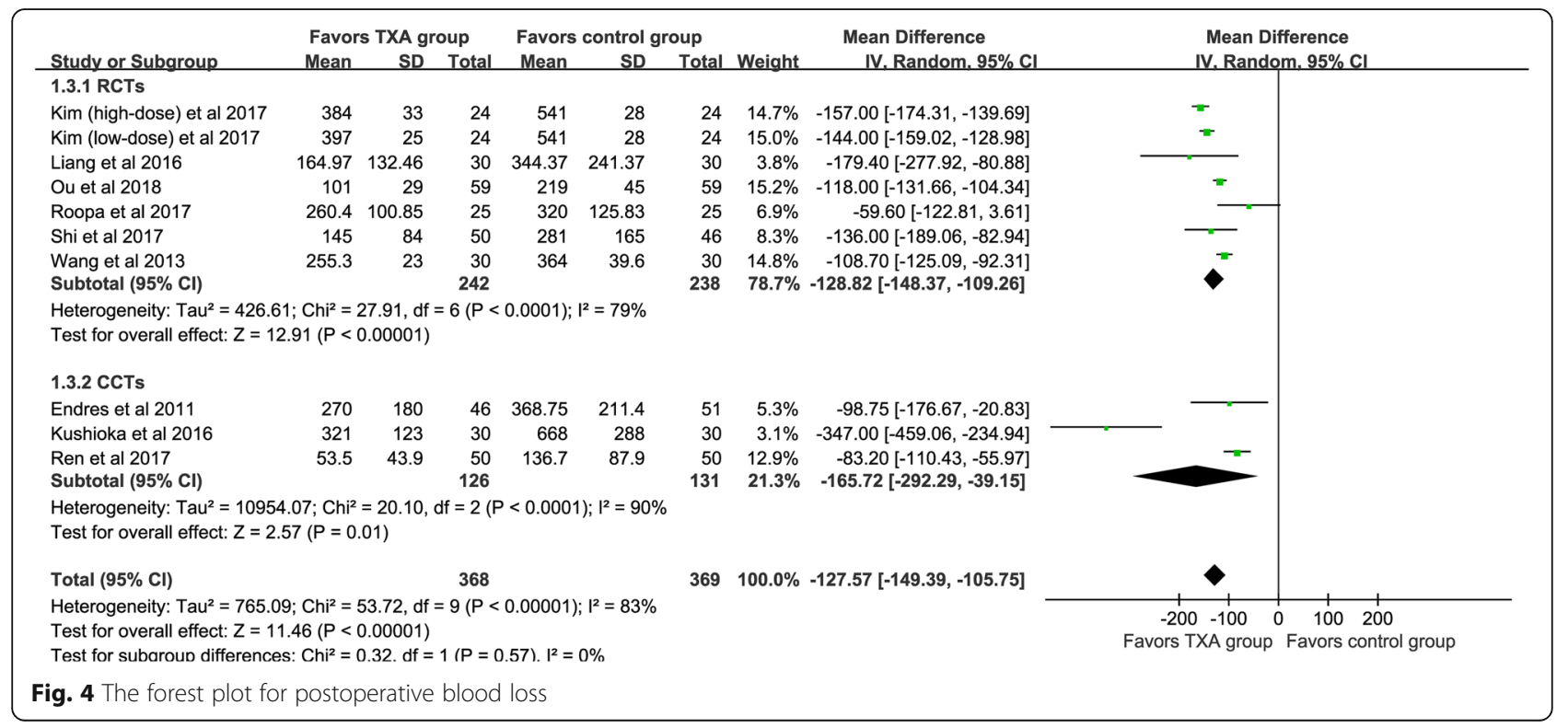




\begin{tabular}{|c|c|c|c|c|c|c|c|c|c|c|c|c|}
\hline \multirow{3}{*}{$\begin{array}{l}\text { Study or Subgroup } \\
1.4 .1 \text { RCTs }\end{array}$} & \multicolumn{3}{|c|}{ Favors TXA group } & \multicolumn{3}{|c|}{ Favors control group } & & \multirow{2}{*}{$\begin{array}{l}\text { Mean Difference } \\
\quad \text { IV. Fixed, } 95 \% \mathrm{Cl}\end{array}$} & \multirow{2}{*}{\multicolumn{4}{|c|}{$\begin{array}{l}\text { Mean Difference } \\
\text { IV. Fixed, } 95 \% \mathrm{Cl}\end{array}$}} \\
\hline & \multirow[t]{2}{*}{ Mean } & \multirow[t]{2}{*}{ SD } & Total & \multirow[t]{2}{*}{ Mean } & \multirow[t]{2}{*}{ SD } & \multirow{2}{*}{\multicolumn{2}{|c|}{ Total Weight }} & & & & & \\
\hline & & & & & & & & & \multirow{2}{*}{\multicolumn{2}{|c|}{$\rightarrow-$}} & \multirow{2}{*}{. } & \\
\hline Kim (high-dose) et al 2017 & 1.3 & 0.6 & 24 & 1.7 & 0.2 & 24 & $27.7 \%$ & $-0.40[-0.65,-0.15]$ & & & & \\
\hline Kim (low-dose) et al 2017 & 1.6 & 0.5 & 24 & 1.7 & 0.2 & 24 & $38.2 \%$ & $-0.10[-0.32,0.12]$ & & & & \\
\hline Liang et al 2016 & 1.93 & 1.55 & 30 & 2.13 & 1.72 & 30 & $2.6 \%$ & $-0.20[-1.03,0.63]$ & & & & \\
\hline Ou et al 2018 & 0.8 & 1.37 & 59 & 1.5 & 1.4 & 59 & $7.1 \%$ & $-0.70[-1.20,-0.20]$ & & . & & \\
\hline Roopa et al 2017 & 1.97 & 1.5 & 25 & 2.57 & 1.61 & 25 & $2.4 \%$ & $-0.60[-1.46,0.26]$ & & & & \\
\hline Shi et al 2017 & 1.5 & 1.6 & 50 & 1.67 & 1.47 & 46 & $4.7 \%$ & $-0.17[-0.78,0.44]$ & & & & \\
\hline Subtotal $(95 \% \mathrm{Cl})$ & & & 212 & & & 208 & $82.7 \%$ & $-0.27[-0.42,-0.13]$ & & 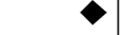 & & \\
\hline \multicolumn{13}{|c|}{$\begin{array}{l}\text { Heterogeneity: } \text { Chi }^{2}=6.94, \text { df }=5(P=0.23) ;\left.\right|^{2}=28 \% \\
\text { Test for overall effect: } Z=3.66(P=0.0003)\end{array}$} \\
\hline \multicolumn{13}{|l|}{ 1.4.2 CCTs } \\
\hline Endres et al 2011 & 3.83 & 0.89 & 46 & 4.21 & 0.9 & 51 & $13.9 \%$ & $-0.38[-0.74,-0.02]$ & & . & & \\
\hline $\begin{array}{l}\text { Kushioka et al } 2016 \\
\text { Subtotal }(95 \% \mathrm{Cl})\end{array}$ & 1.8 & 1.3 & $\begin{array}{l}30 \\
76\end{array}$ & 2.7 & 1.55 & $\begin{array}{l}30 \\
81\end{array}$ & $\begin{array}{r}3.4 \% \\
17.3 \%\end{array}$ & $\begin{array}{l}-0.90[-1.62,-0.18] \\
-0.48[-0.80,-0.16]\end{array}$ & & & & \\
\hline \multicolumn{13}{|c|}{$\begin{array}{l}\text { Heterogeneity: } \mathrm{Chi}^{2}=1.60, \mathrm{df}=1(P=0.21) ; I^{2}=37 \% \\
\text { Test for overall effect: } Z=2.95(P=0.003)\end{array}$} \\
\hline & \multirow{2}{*}{\multicolumn{2}{|c|}{ Heterogeneity: $\mathrm{Chi}^{2}=9.88, \mathrm{df}=7(P=0.20) ;\left.\right|^{2}=29 \%$}} & 288 & & & 289 & $100.0 \%$ & $-0.31[-0.44,-0.18]$ & & $\bullet$ & & \\
\hline \multicolumn{7}{|c|}{$\begin{array}{l}\text { Test for overall effect: } Z=4.56(P<0.00001) \\
\text { Test for subaroun differences: } \mathrm{Chi}^{2}=1.34 . \mathrm{df}=1(\mathrm{P}=0.25) . \mathrm{I}^{2}=25.5 \%\end{array}$} & & & \multicolumn{4}{|c|}{$\begin{array}{lcccc}-2 & -1 & 0 & 1 & 2 \\
\text { Favors TXA group } & \text { Favors control group }\end{array}$} \\
\hline Fig. 5 The forest plot for & ostope & ative 2 & $-\mathrm{h} \mathrm{Hb}$ & decline & lue & & & & & & & \\
\hline
\end{tabular}

\section{Different study designs}

We divided the included studies into RCTs and CCTs, and subgroup analysis based on different designs of the studies. For TBL (shown in Fig. 2), four RCTs demonstrated that the TXA could decrease TBL [WMD =183.96, 95\% CI $\left.(-228.31,-139.60), P<0.001, I^{2}=26 \%\right]$. The results of the pooled of the two CCTs were similar to the former [WMD $=-385.54,95 \%$ CI $(-603.37$, 167.71), $P<0.001, \mathrm{I}^{2}=79 \%$. Six RCTs and three CCTs provide available data, respectively, and the pooled results showed that TXA could significantly reduce the IBL $(P<0.05$, shown in Fig. 3$)$. Similarly, both types of studies have shown that TXA can significantly reduce the PBL in patients $(P<0.05$, shown in Fig. 4$)$. Five RCTs and two CCTs provide available data, and the results showed that TXA group had a lower postoperative $\mathrm{Hb}$ decline value $(P<0.05$, shown in Fig. 5$)$.

\section{Studies with different quality}

The quality score of the CCTs was more than 7 points and considered as high-quality studies, so no subgroup analysis was performed. For RCTs, the pooled results of the high-quality studies showed that TXA group had a significant decrease in TBL, IBL, PBL, and the loss of $\mathrm{Hb}$ than the control group $(P<0.05$, shown in Table 4). For RCTs with moderate quality, the pooled outcomes demonstrated that the TXA group has less blood loss than the control group, similar to high-quality RCTs (shown in Table 4), but there is no significant difference between the two groups in IBL $(P=0.08$, shown in Table 4$)$, which may be caused by the limitation of studies.

\section{Sensitivity analysis}

Due to the limited number of studies in tTXA and combined IV with topical administration, we only conducted sensitivity analysis in the data of IV TXA. The exclusion of each study once a time in TBL, IBL, PBL, and postoperative $24 \mathrm{~h} \mathrm{HB}$ decline, and all the conclusions kept stable.

\section{Discussion}

The main findings of this meta-analysis demonstrated that TXA could decrease the postoperative $\mathrm{Hb}$ loss, TBL, IBL, PBL, and without increasing the risk of the thrombotic event in PLF surgery. However, there is no

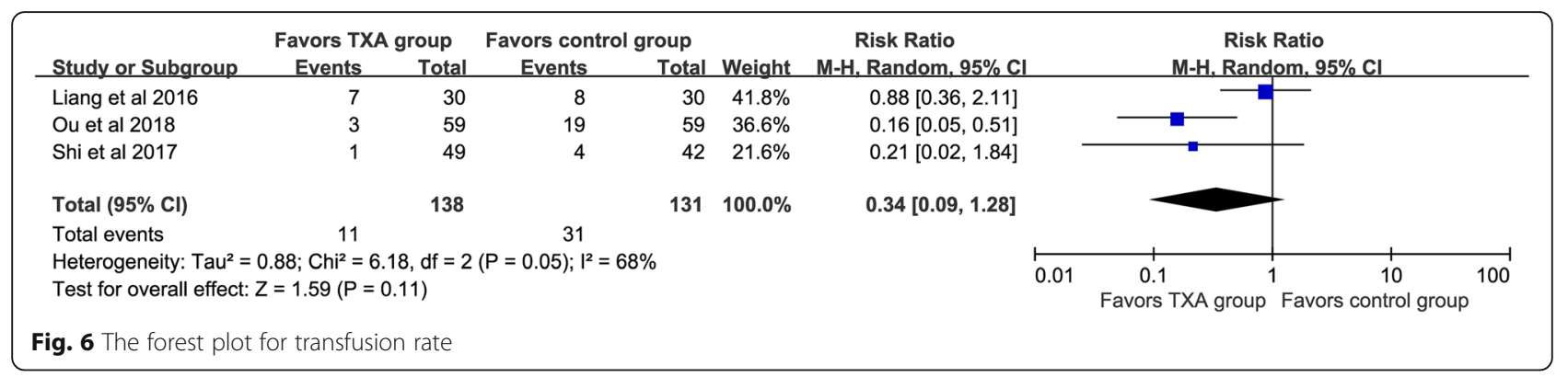



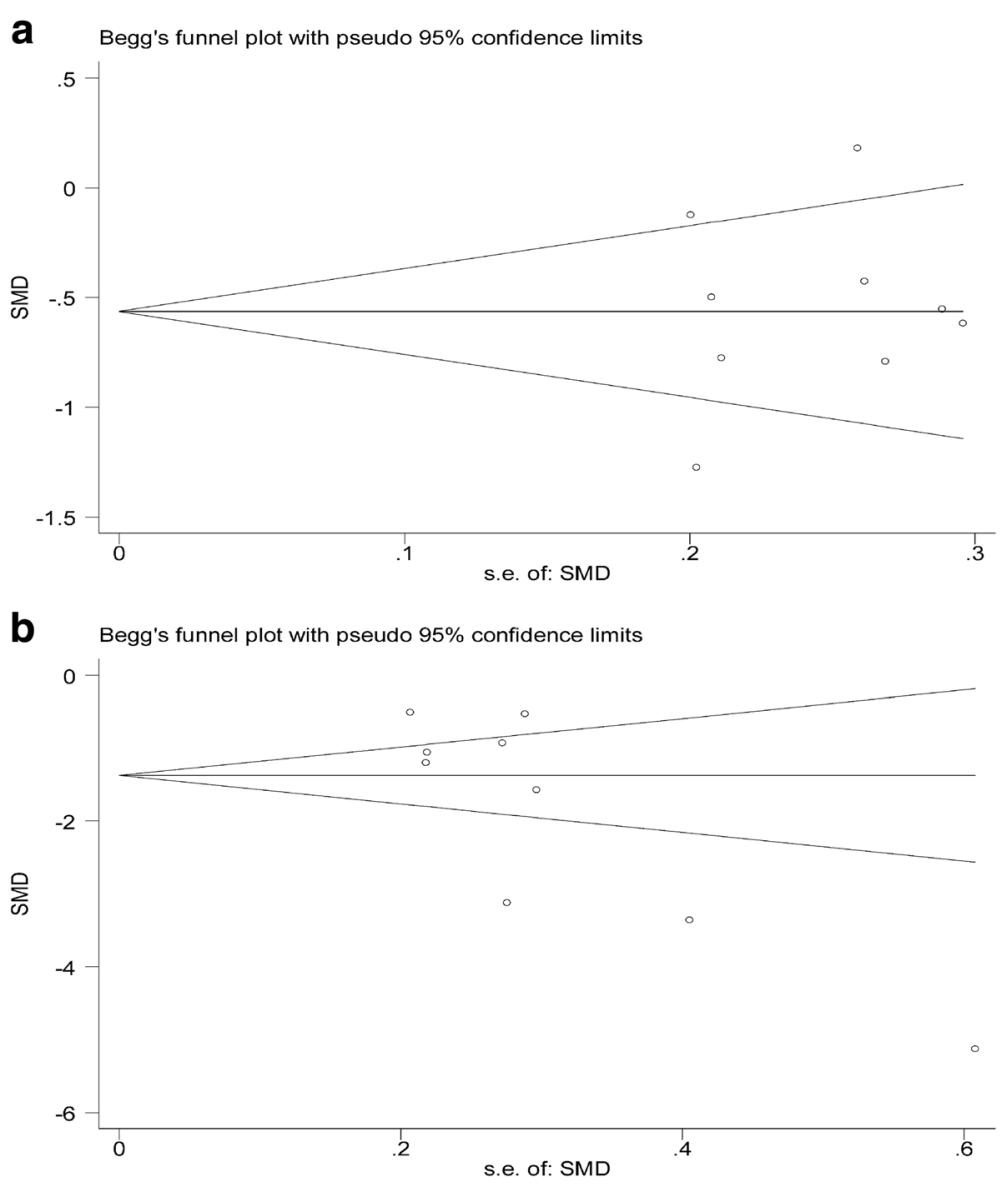

Fig. 7 a The funnel plot for intraoperative blood loss. $\mathbf{b}$ The funnel plot for postoperative blood loss

statistical difference in transfusion rate between the two groups. The results of our meta-analysis demonstrated that the hemostasis effect of TXA in PLF surgery was similar to scoliosis surgery [14].

TXA has been widely used in clinical treatment as a hemostatic agent, and it was included on the WHO list as an essential medicine in 2011 [29]. The safety of TXA has been confirmed in obstetric surgery, hip and knee joint replacement, coronary-artery and other surgeries [6-8]. The study of Benoni et al. pointed out that TXA does not increase the risk of DVT, and it just inhibits fibrinolysis in the wound to play a hemostasis effect [30]. A large sample size study involving 872,416 patients demonstrated that TXA does not increase the risk of postoperative complications [31]. No thromboembolic events were found in TXA groups as well in our meta-analysis. However, due to the lack of literature and the different route of administration, the conclusion of transfusion rate is not convincing.

IBL directly affects the operation time and visible surgical field, so it is of considerable significance to the surgery. However, it is unclear whether tTXA can significantly reduce IBL in PLF surgery. The study of Ren et al. indicated that tTXA had a similar effect to the control group in PLF surgery [27]. But Liang et al. point out that TXA soaked gelfoam group had a similar amount of blood loss compared with gelfoam group during the PLF surgery [21]. tTXA was mainly absorbed into the blood to exert the hemostatic effect. Whether tTXA could quickly exert hemostatic effect to decrease IBL during PLF surgery should be taken into consideration.

It is unclear whether the effect of combined IV administration with topical application of TXA is superior to single-use of TXA. The meta-analysis of Sun et al. [32] demonstrated that IV combine with tTXA was better than IV TXA in total hip replacement regarding blood loss, hemoglobin decline, and transfusion rate. Yang et al's study [33] indicated that the combined administration of TXA in total joint arthroplasty was superior to the single use of TXA. Ou et al's study [25] suggested that combined IV administration with topical application of TXA could significantly decrease allogeneic blood transfusion and blood loss in PLF surgery. Therefore, it is of some significance to consider this method in spinal surgery.

Currently, there was no guideline to specify the dosage of TXA in spine surgery. Kim et al's study [22] suggested that high-dose TXA $(10 \mathrm{mg} / \mathrm{kg}$ of bolus loading dose 
Table 4 Subgroup analysis based on the route of administration and the study quality

\begin{tabular}{|c|c|c|c|c|c|c|}
\hline Outcomes & Subgroup & Study (N) & RR/WMD & $95 \% \mathrm{Cl}$ & $1^{2}(\%)$ & $P$ \\
\hline \multirow[t]{3}{*}{ Total blood loss } & IV TXA & 4 & -287.25 & $(-411.81,-162.70)$ & 79 & $<0.001$ \\
\hline & tTXA & 1 & -283 & $(-394.09,-171.91)$ & - & $<0.001$ \\
\hline & Combined & 1 & -165 & $(-220.77,-109.23)$ & - & $<0.001$ \\
\hline \multirow[t]{3}{*}{ Intraoperative blood loss } & IV TXA & 6 & -82.73 & $(-122.80,-42.66)$ & 48 & $<0.001$ \\
\hline & tTXA & 2 & -17.25 & $(-63.51,29.00)$ & 0 & 0.46 \\
\hline & Combined & 1 & -102 & $(-130.87,-73.13)$ & - & $<0.001$ \\
\hline \multirow[t]{3}{*}{ Postoperative blood loss } & IV TXA & 6 & -135.66 & $(-164.24,-107.08)$ & 84 & $<0.001$ \\
\hline & tTXA & 2 & -119.17 & $(-210.40,-27.94)$ & 71 & $<0.001$ \\
\hline & Combined & 1 & -118 & $(-131.66,-104.34)$ & - & $<0.001$ \\
\hline \multirow[t]{3}{*}{ Postoperative $24 \mathrm{~h} \mathrm{HB}$ decline } & IV TXA & 5 & -0.28 & $(-0.42,-0.14)$ & 32 & $<0.001$ \\
\hline & tTXA & 1 & -0.2 & $(-1.03,0.63)$ & - & 0.64 \\
\hline & Combined & 1 & -0.7 & $(-1.20,-0.2)$ & - & 0.006 \\
\hline \multirow[t]{2}{*}{ Total blood loss } & High & 4 & -208.93 & $(-286.07,-131.78)$ & 42 & $<0.001$ \\
\hline & Moderate & 1 & -165.00 & $(-220.77,-109.23)$ & - & $<0.001$ \\
\hline \multirow[t]{2}{*}{ Intraoperative blood loss } & High & 4 & -64.12 & $(-108.32,-19.91)$ & 31 & 0.004 \\
\hline & Moderate & 2 & -70.73 & $(-150.56,9.11)$ & 68 & 0.08 \\
\hline \multirow[t]{2}{*}{ Postoperative blood loss } & High & 4 & -128.51 & $(-153.93,-103.08)$ & 83 & $<0.001$ \\
\hline & Moderate & 2 & -128.52 & $(-173.86,-83.18)$ & 32 & $<0.001$ \\
\hline \multirow[t]{2}{*}{ Postoperative $24 \mathrm{~h} \mathrm{HB}$ decline } & High & 3 & -0.23 & $(-0.39,-0.08)$ & 23 & 0.003 \\
\hline & Moderate & 2 & -0.57 & $(-0.99,-0.14)$ & 3 & 0.009 \\
\hline
\end{tabular}

IV: intravenous use of TXA; tTXA: topical use of TXA; Combined: combined IV administration and topical application of TXA; -: no available; High: high quality; Moderate: moderate quality

and $2 \mathrm{mg} / \mathrm{kg} / \mathrm{h}$ of continuous infusion) was more effective than low-dose TXA in the decrease of blood loss in PLF surgery. Xie et al's study [34] suggested that highdose TXA (100 mg/Kg of bolus loading dose and $10 \mathrm{mg} /$ $\mathrm{Kg} / \mathrm{h}$ until skin closure) could effectively control blood loss and reduce the transfusion requirement without adverse drug reactions in spine correction surgery. The study of Kushioka [26] demonstrated that high-dose TXA (2000 mg) decreased both IBL and PBL without causing any side effects in PLF surgery. A recent metaanalysis suggested that high-dose TXA has a better hemostatic effect than the control group in patients underwent PLF surgery [35], but the dose of TXA administered during and after the operation is different in the included studies, so the conclusion needs further discussion. Lin et al. [36] pointed out high-dose $(50 \mathrm{mg} / \mathrm{kg}$ IV loading dose followed by a $5-\mathrm{mg} / \mathrm{kg} / \mathrm{h}$ infusion until skin closure) was efficacy in complex adult spinal deformity surgery, but there were three thromboembolic postoperative complications. The dosages of TXA should be determined according to the type of spinal surgery, the patient's conditions (e.g., weight, renal function) and other factors. Besides, the relevant dose-response analysis should be performed to identify the optimal TXA dose in spinal surgery.
We recommend future research as follows. (1) The most appropriate time and dosage for TXA need further study. (2) Topical TXA is considered to have less influence on the systemic fibrinolytic system and is safer than IV TXA, but its efficacy requires further research. (3) It is unclear whether the use of combined IV administration and topical application of TXA is superior to IV in spinal surgery. (4) For spinal surgery, PBL may increase the formation of epidural hematomas that cause neurological disorders [37]. Combined with Table 1 and Fig. 4, we can see that postoperative TXA can significantly reduce the amount of PBL in patients, so whether TXA is needed after surgery for patients with suspected bleeding should be made the further study. (5) Most of the previous studies have excluded patients with severe heart and lung diseases, however, for these patients, reducing blood loss in perioperative blood loss is truly meaningful, so relevant research should be further exploring the use of TXA in these type patients in spinal surgery. (6) It has been reported that oral administration of TXA had comparable hemostasis effect to IV TXA and topical TXA in total hip/knee arthroplasty [38], and it has been found with higher safety level. Therefore, it is significant to consider oral TXA in spinal surgery.

Limitations are as follows. (1) Due to the lack of guidelines for clinical use of TXA, the doses and timing of TXA 
usage are unequal in the included studies. It was impossible to perform sub-analysis of them to make a further explanation. (2) Some pooled outcomes have higher heterogeneity, different time and the dose of tranexamic acid used, and diverse transfusion criteria may be contributed to it. (3) Most studies included in this meta-analysis were small sample size and some non-RCTs, which may affect the reliability of the conclusions.

\section{Conclusion}

Our meta-analysis demonstrated that TXA can decrease the $\mathrm{Hb}$ loss, TBL, IBL, PBL, and without increasing the risk of thrombotic event in patients with degenerative lumbar disc herniation, stenosis or instability underwent PLF surgery. However, there was no significant difference in blood transfusion rates between the two groups.

\section{Abbreviations}

CCTs: Case control trials; $\mathrm{Cl}$ : Confidence intervals; Hb: Hemoglobin; $\mathrm{I}^{2}$ : Isquare; IBL: Intraoperative blood loss; IV: Intravenous use of TXA; PBL: Postoperative blood loss; PLF: Posterior lumbar fusion; RCTs: Randomized controlled trials; RR: Relative risk; TBL: Total blood loss; tTXA: topical use of TXA; TXA: Tranexamic acid; WMD: Weighted mean difference

\section{Acknowledgements}

We thank the authors of the included studies for their helping.

\section{Authors' contributions}

WJ, WY, BJ, and ZP conceived of the design of the study. BJ and LY participated in the literature search, study selection, data extraction and quality assessment. BJ and ZP performed the statistical analysis. BJ finished the manuscript. All authors read and approved the final manuscript.

\section{Funding}

This study was supported by the grants from National Natural Science Foundation of China: (81772332), Natural Science Foundation of Jiangsu Province (BK20141281), Special Foundation Project on the Prospective Study of Social Development in Jiangsu Province (BE2013911), Jiangsu Six Categories of Talent Summit Fund (WSW-133), Social Development of Science and Technology Research Project in Yangzhou (YZ2011082), and Jiangsu Province 333 talent Project (BRA2016159). These above funding mainly provide fund support in manuscript writing, data analysis, and publication fee.

\section{Availability of data and materials}

All data are fully available without restriction.

Ethics approval and consent to participate

All analyses were based on previous published studies; thus, no ethical approval and patient consent are required.

\section{Consent for publication}

Not applicable.

\section{Competing interests}

The authors declare that they have no competing interests.

\section{Author details}

'Department of Orthopedics, Clinical Medical College of Yangzhou University, Northern Jiangsu People's Hospital, Nantong West Road 98, Yangzhou 225001, China. ${ }^{2}$ Dalian Medical University, Dalian 116044, Liaoning, China.
Received: 21 June 2018 Accepted: 14 August 2019

Published online: 31 August 2019

\section{References}

1. Allain JP, Stramer SL, Carneiro-Proietti AB, Martins ML. Lopes da Silva SN, Ribeiro M, Proietti FA, Reesink HW. Transfusion-transmitted infectious diseases. Biologicals. 2009;37(2):71-7.

2. Vamvakas EC, Blajchman MA. Transfusion-relevanted mortality: the ongoing risks of allogeneic blood transfusion and the available strategies for their prevention. Blood. 2009;113(15):3406-17.

3. Hu SS. Blood loss in adult spinal surgery. Eur Spine J. 2004;13(Suppl 1):S3-5.

4. Hardy JF, Desroches J. Natural and synthetic antifibrinolytics in cardiac surgery. Can J Anaesth. 1992;39(4):353-65.

5. Eubanks JD. Antifibrinolytics in major orthopaedic surgery. J Am Acad Orthop Surg. 2010;18(3):132-8

6. Ngichabe $\mathrm{S}$, Obura T, Stones $\mathbf{W}$. Intravenous tranexamic acid as an adjunct haemostat to ornipressin during open myomectomy. A randomized double blind placebo controlled trial. Ann Surg Innov Res. 2015;9:10.

7. Myles PS, Smith JA, Painter T. Tranexamic acid in patients undergoing coronary-artery surgery. N Engl J Med. 2017;376(19):1893.

8. Zhang P, Liang Y, Chen P, Fang Y, He J, Wang J. Combined application versus topical and intravenous application of tranexamic acid followingprimary total hip arthroplasty: a meta-analysis. BMC Musculoskelet Disord. 2017;18(1):90.

9. Hui S, Xu D, Ren Z, Chen X, Sheng L, Zhuang Q, Li S. Can tranexamic acid conserve blood and save operative time in spinal surgeries? A metaanalysis. Spine J. 2017;17:31192 0.

10. Cheriyan T, Maier SP 2nd, Bianco K, Slobodyanyuk K, Rattenni RN, Lafage V, Schwab FJ, Lonner BS, Errico TJ. Efficacy of tranexamic acid on surgical bleeding in spine surgery: a meta-analysis. Spine J. 2015;15(4):752-61.

11. Badeaux J, Hawley D. A systematic review of the effectiveness of intravenous tranexamic acid administration in managing perioperative blood loss in patients undergoing spine surgery. J Perianesth Nurs. 2014; 29(6):459-65.

12. Zhang F, Wang K, Li FN, Huang X, Li Q, Chen Z, Tang YB, Shen HX, Song QX. Effectiveness of tranexamic acid in reducing blood loss in spinal surgery: a meta-analysis. BMC Musculoskelet Disord. 2014;15:448.

13. Alajmi $T$, Saeed $H$, Alfaryan $K$, Alakeel A, Alfaryan T. Efficacy of tranexamic acid in reducing blood loss and blood transfusion in idiopathic scoliosis: a systematic review and meta-analysis. J Spine Surg. 2017;3(4):531-40.

14. Yuan QM, Zhao ZH, Xu BS. Efficacy and safety of tranexamic acid in reducing blood loss in scoliosis surgery: a systematic review and metaanalysis. Eur Spine J. 2017;26(1):131-9.

15. Liberati A, Altman DG, Tetzlaff J, Mulrow C, Gøtzsche P PRISMA Group. The PRISMA statement for reporting systematic reviews and meta-analyses of studies that evaluate health care interventions: Explanation and elaboration. PLoS Med. 2009;6:e1000100.

16. Furlan AD, Malmivaara A, Chou R, et al. 2015 updated method guideline for systematic reviews in the Cochrane Back and neck group. Spine. 2015; 40(21):1660-73.

17. Uçeyler N, Häuser W, Sommer C. Systematic review with meta-analysis: cytokines in fibromyalgia syndrome. BMC Musculoskelet Disord. 2011;12:245

18. Ren Z, Li S, Sheng L, Zhuang Q, Li Z, Xu D, Chen X, Jiang P, Zhang X. Efficacy and safety of topical use of tranexamic acid in reducing blood loss during primary lumbar spinal surgery: a retrospective case control study. Spine. 2017:42(23):1779-84

19. Xu D, Zhuang Q, Li Z, Ren Z, Chen X, Li S. A randomized controlled trial on the effects of collagen sponge and topical tranexamic acid in posterior spinal fusion surgeries. J Orthop Surg Res. 2017;12(1):166.

20. Wang Q, Liu J, Fan R, Chen Y, Yu H, Bi Y, Hua Z, Piao M, Guo M, Ren W, Xiang L. Tranexamic acid reduces postoperative blood loss of degenerative lumbar instability with stenosis in posterior approach lumbar surgery: a randomized controlled trial. Eur Spine J. 2013;22(9):2035-8.

21. Liang J, Liu H, Huang X, Xiong W, Zhao H, Chua S, Li Z. Using tranexamic acid soaked absorbable gelatin sponge following complex posterior lumbar spine surgery: a randomized control trial. Clin Neurol Neurosurg. 2016;147:110-4.

22. Kim KT, Kim CK, Kim YC, Juh HS, Kim HJ, Kim HS, Hong SJ, Hey HWD. The effectiveness of low-dose and high-dose tranexamic acid in posterior lumbar interbody fusion: a double-blinded, placebo-controlled randomized study. Eur Spine J. 2017;26(11):2851-7. 
23. Shi H, Ou Y, Jiang D, Quan Z, Zhao Z, Zhu Y. Tranexamic acid reduces perioperative blood loss of posterior lumbar surgery for stenosis or spondylolisthesis: a randomized trial. Medicine. 2017;96(1):e5718.

24. Roopa MN, Nagabhushan RM, Shetty AP, Dumpa SR, Subramanian B, Kanna RM, Shanmuganathan R. Effectiveness and safety of Batroxobin, tranexamic acid and a combination in reduction of blood loss in lumbar spinal fusion surgery. Spine. 2018;43(5):E267-e273.

25. Ou Y, Wei J, Li R, Liang B, Qiu D, Wei M, Mu X, Li Z. Clinical research of combined intravenous administration and topical application of tranexamic acid to a surgical wound during posterior lumbar fusion. Surg Innov. 2018;25(2):128-35.

26. Kushioka J, Yamashita T, Okuda S, Maeno T, Matsumoto T, Yamasaki R, Iwasaki M. High-dose tranexamic acid reduces intraoperative and PBL in posterior lumbar interbody fusion. J Neurosurg Spine. 2017;26(3):363-7.

27. Ren Z, Li S, Sheng L, Zhuang Q, Li Z, Xu D, Chen X, Jiang P, Zhang X. Topical use of tranexamic acid can effectively decrease hidden blood loss during posterior lumbar spinal fusion surgery: a retrospective study. Medicine. 2017;96(42):e8233.

28. Endres $\mathrm{S}$, Heinz M, Wilke A. Efficacy of tranexamic acid in reducing blood loss in posterior lumbar spine surgery for degenerative spinal stenosis with instability: a retrospective case control study. BMC Surg. 2011;11:29.

29. WHO Expert Committee on the Selection and Use of Essential Medicines. Summary of the report of the 18th meeting of theWHO Expert Committee on the Selection and Use of EssentialMedicines. 2011. Available at: http:// www.who.int/selection_medicines/committees/TRS_web_summary.pdf. Accessed 20 Mar 2015.

30. Benoni $\mathrm{G}$, Fredin $\mathrm{H}$. Fibrinolytic inhibition with tranexamic acid reduces blood loss and blood transfusion after knee arthroplasty: a prospective, randomised, double-blind study of 86 patients. J Bone Joint Surg Br. 1996; 78(3):434-40.

31. Poeran J, Rasul R, Suzuki S, Danninger T, Mazumdar M, Opperer M, Boettner F, Memtsoudis SG. Tranexamic acid use and postoperative outcomes in patients undergoing total hip or knee arthroplasty in the United States: retrospective analysis of effectiveness and safety. BMJ. 2014;349:94829.

32. Sun Y, Jiang C, Li Q. A systematic review and meta-analysis comparing combined intravenous and topical tranexamic acid with intravenous administration alone in THA. PLoS One. 2017;12(10):e0186174.

33. Yang L, Du S, Sun Y. Is combined topical and intravenous tranexamic acid superior to single use of tranexamic acid in total joint arthroplasty?: a metaanalysis from randomized controlled trials. Medicine. 2017;96(30):e7609.

34. Xie J, Lenke LG, Li T, Si Y, Zhao Z, Wang Y, Zhang Y, Xiao J. Preliminary investigation of high-dose tranexamic acid for controlling intraoperative blood loss in patients undergoing spine correction surgery. Spine J. 2015;15(4):647-54.

35. Gong M, Liu G, Chen L, Chen R, Xiang Z. The efficacy and safety of intravenous tranexamic acid in reducing surgical blood loss in posterior lumbar interbody fusion for the adult: a systematic review and a metaanalysis. World Neurosurg. 2019;122:559-68.

36. Lin JD, Lenke LG, Shillingford JN, Laratta JL, Tan LA, Fischer CR, Weller MA, Lehman RA Jr. Safety of a high-dose tranexamic acid protocol in complex adult spinal deformity: analysis of 100 consecutive cases. Spine Deform. 2018:6(2):189-94.

37. Sokolowski MJ, Garvey TA, Perl J 2nd, Sokolowski MS, Cho W, Mehbod AA, Dykes DC, Transfeldt EE. Prospective study of postoperative lumbar epidural hematoma: incidence and risk factors. Spine. 2008;33(1):108-13.

38. Cao G, Huang Q, Huang Z, Zhang S, Luo Z, Lei Y, Zhou Z, Pei F. The efficacy and safety of multiple-dose oral tranexamic acid on blood loss following total hip arthroplasty: a randomized controlled trial. Int Orthop. 2019;43(2): 299-305.

\section{Publisher's Note}

Springer Nature remains neutral with regard to jurisdictional claims in published maps and institutional affiliations.

Ready to submit your research? Choose BMC and benefit from:

- fast, convenient online submission

- thorough peer review by experienced researchers in your field

- rapid publication on acceptance

- support for research data, including large and complex data types

- gold Open Access which fosters wider collaboration and increased citations

- maximum visibility for your research: over $100 \mathrm{M}$ website views per year

At BMC, research is always in progress.

Learn more biomedcentral.com/submissions 